\title{
ATP luminescence assay as a bioburden estimator of biomass accumulation in caves
}

\author{
Janez Mulec ${ }^{*}$ and Andreea Oarga-Mulec ${ }^{2}$ \\ ${ }^{1}$ Karst Research Institute, Research Centre of the Slovenian Academy of Sciences and Arts, Titov trg 2, 6230 Postojna, Slovenia \\ ${ }^{2}$ Laboratory for Environmental Research, University of Nova Gorica, Vipavska 13, 5000 Nova Gorica, Slovenia
}

\begin{abstract}
A commercially available adenosine triphosphate (ATP) detection system (Hygiena, USA), supported by cultivable microbial indicators, was used to estimate bioburden in different habitats in and outside show caves: air, water and solid surfaces. A strong positive correlation between ATP concentration expressed as Relative Light Units (RLU) and Colony-Forming-Units (CFU) was observed for swab samples from cave surfaces. In terms of ATP units, surfaces in a single cave system (Postojna Cave) varied considerably (240-1,258,800 RLU/ $\left.20 \mathrm{~cm}^{2}\right)$ and commonly exceeded the bioburden level of analogues on the surface $\left(0-114,390 \mathrm{RLU} / 20 \mathrm{~cm}^{2}\right)$. Cave sub-habitats were colonized by physiologically distinct microbial communities in terms of their nutrient demands, temperature requirements and $\mathrm{r} / \mathrm{K}$ growth strategy. The highest ATP biomass indicator $\left(1,258,800 \mathrm{RLU} / 20 \mathrm{~cm}^{2}\right)$ for the speleothem that had been touched but accompanied with comparable concentration of CFU $\left(\sim 10^{6} \mathrm{CFU} / 20 \mathrm{~cm}^{2}\right)$ for other cave sub-habitats, can be related to the presence of deposited human epithelium skin cells. Show cave infrastructures containing heavy metals, e.g. copper used in safety fences, reduce the viability of microbiota. Mass cave visitation and the presence of allochthonous organic matter result in high levels of airborne and total biomass. Once such material becomes airborne, the location of its settling depends upon natural and humaninduced air movements. Underground habitats play an important role in the preservation and concentration of microbial biomass using air and water as transport mechanisms.
\end{abstract}

Keywords: $\quad$ underground, biomass, swab, air, water, microorganisms

Received 25 January 2016; Revised 17 July 2016; Accepted 20 July 2016

Citation: Mulec J. and Oarga-Mulec A., 2016. ATP luminescence assay as a bioburden estimator of biomass accumulation in caves. International Journal of Speleology, 45 (3), 207-218. Tampa, FL (USA) ISSN 0392-6672 http://dx.doi.org/10.5038/1827-806X.45.3.1975

\section{INTRODUCTION}

Microbes face stressful environmental conditions during transfer through the atmosphere (Morris et al., 2011) and also within water (Balkwill et al., 1998). Having successfully overcome stressors while in transit and reached the new destination, preservation of their viability is further challenged by different factors. Once the microbes are in contact with the surface, their fate depends upon their ecophysiological capabilities (Guerrero et al., 2002; Schimel et al., 2007), substrate characteristics (Warscheid \& Braams, 2000), environmental conditions, e.g. UV (WynnWilliams \& Edwards, 2002), desiccation (Barnard et al., 2013), and interactions with any (eventual) preexisting microbiota (Friman et al., 2014). An example of constant transport of microbes passing different barriers is provided by karst caves, which commonly show good connectivity with the surface through many fissures and voids (Ford \& Williams, 2007). Caves can thus serve as models for the transport of particulate material, and for microbial interactions, because some natural stressors, such as UV and desiccation, are absent (Summers Engel \& Northup, 2008; Hauer et al., 2015). Accurate sampling and determination of microbial biomass in these habitats is normally one of the prerequisites that direct downstream analyses.

Direct microscopic fluorescent counts using nucleic-acids-staining dyes represent a good start in evaluating the microbial abundance rather than biomass (Norland, 1993; Senjarini et al., 2013). Different protocols based on fluorochrome-stained cells have been developed for distinct samples and applications (Cragg and Parkes, 2014). Techniques based on specific monoclonal antibodies represent another powerful tool to study microbial populations from natural environments (Hamasaki et al., 2016). Furthermore, nowadays, nucleic acids probing coupled with specific techniques offers powerful insights into individual constituents of the natural occurring microbial community, for example Fluorescence In Situ Hybridization (FISH) and its combinations with 
microautoradiography, Raman spectroscopy and secondary ion mass spectroscopy (Musat et al., 2012). Flow cytometry is not used solely to estimate microbial biomass, but serves also for rapid microbial community fingerprinting (De Roy et al., 2012) and for tracking the changes in microbial subpopulations or on a single-cell level (Sgier et al., 2016).

Quantitative measurements of microbial cellular components give a reliable estimation of the biomass (White et al., 1997) and of community structure and functioning (Röling \& van Bodegom, 2014). For example, lipid phosphate or phospholipid esterlinked fatty acids provide a quantitative measure for microbes with intact cellular membrane (Gottschalk, 2012), and lipopolysaccharides (LPS) as essential life molecules for the Gram-negative bacteria (Botos et al., 2016) are used specifically to estimate their presence in the environment (Parker et al., 1982). Adenosine triphosphate (ATP) is a universal measure of metabolizing cells (Karl, 1993). Levels of environmental microbial ATP correlate strongly with the results of aerobic plate counts (Chen \& Godwin, 2006). ATP-based methods have previously been used in environmental microbiology, for example, to measure microbial activity in aquatic environments (Hammes et al., 2010), in marine oil spills (Röling \& van Bodegom, 2014), in mineral leach liquors (Okibe \& Johnson, 2011) and in an orthoquartzite (quartz-cemented sandstone) cave (Barton et al., 2014). The surfaces from this cave contained a high level of microbial biomass determined by an ATPbased luminescence assay when compared to other (carbonate) cave systems (Barton et al., 2014).

Even though cultivable microbes represent only a very small part of the community (Stewart, 2012), cultivation is still widely used as a routine laboratory procedure to quantify environmental indicators, estimate biomass and, particularly, in efforts to isolate new, biotechnologically important microorganisms (Bull et al., 2000; Giovannoni \& Stingl, 2007). Data on bacterial growth dynamics on a nonselective agar medium can be used to work out their growth strategy. As a community develops, fast growing opportunistic species (r-strategists) are gradually replaced by slowgrowing equilibrium species (K-strategists). The ratio of $\mathrm{r}$ - vs. K-strategists is a measure for a succession state in a microbial community (Krištůfek et al., 2005; Andrews \& Harris, 2013).

The objective of the study was to test the versatility of ATP biomass indicator (Hygiena, USA) in different natural environments: air, water, and substrate surfaces that included samples from underground karst and corresponding aboveground analogues. Particularly in karst caves, a continuous flow of organic material and biota is well displayed (Pronk et al., 2006). In parallel with standard cultivation techniques, the biological burden of different cave sub-habitats expressed in ATP biomass was used to estimate the level of naturally occurring and human-induced microbial biomass in underground situations. This relative simple and affordable method has a potential for a wider use in cave microbiology and cave management, as a monitoring tool in efforts to restrict the adverse human impact on a cave ecosystem.

\section{MATERIALS AND METHODS}

\section{Caves}

Different sites in two Slovenian caves were selected for the study. The Postojna Cave system (including Črna jama, Magdalena jama, Otoška jama, Pivka jama and Postojnska jama) formed in Cretaceous limestone (Šebela, 2012) is $24.1 \mathrm{~km}$ long, with the underground Pivka River, which sinks at $511 \mathrm{~m}$ a.s.1. (4546'56.94”N, 14²'12.10”E). The Postojna Cave system occupies $3,066,517 \mathrm{~m}^{3}$ of underground space, with 1,231,716 $\mathrm{m}^{2}$ of contact surfaces (Franjo Drole, personal communication). A $5.0 \mathrm{~km}$ section of Postojna Cave (Postojnska jama) is visited by more than 500,000 tourists each year (in the last two years approximately 640,000 per year), and includes a $3.2 \mathrm{~km}$ round trip by underground railway (Fig. 1). The extent of tourist footpaths is approximately $3,788 \mathrm{~m}^{2}$. The railway lines lie on 5,300 wooden ties (contact surface of each tie is $0.82 \mathrm{~m}^{2}$ ). The tourist use of Postojna Cave is reflected in cave climate, crushed-sand and metal dust from beneath the train wheels, surface contamination, light eutrophication, lampenflora growth and the presence of ultrasonic smog (Šebela \& Turk, 2011; Muri et al., 2013; Šebela et al., 2013; Mulec, 2014; Šebela \& Turk, 2014; Šbela et al., 2015). Some $7 \mathrm{~km}$ towards the northwest, Predjama Cave (Predjama, 4548'55.89"N, $14^{\circ} 7$ '35.56"E), which formed in Cretaceous limestone, Upper Triassic dolomite and Jurassic limestone and dolomite (Čar \& Šebela, 2001), is $13.1 \mathrm{~km}$ long with the Lokva River, which sinks at $462 \mathrm{~m}$ a.s.1. Some galleries host bat colonies (Presetnik et al., 2009;
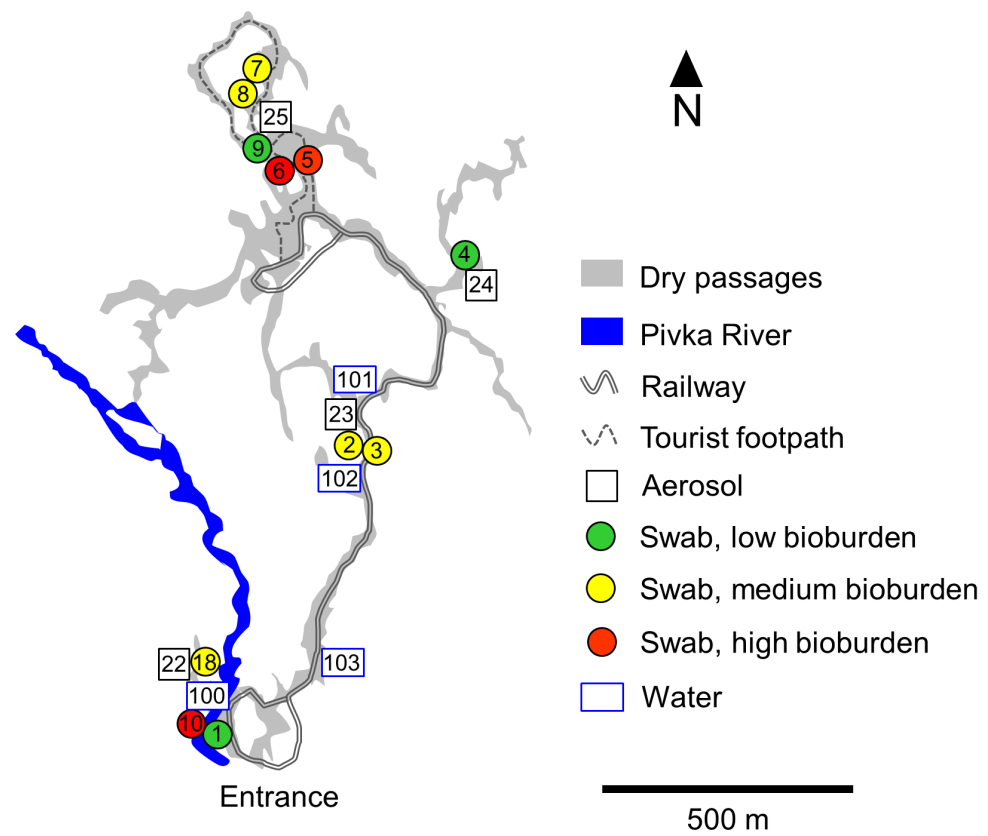

Fig. 1. Sampling sites of settled aerosols, swabs, and waters in Postojna Cave (see Table 1 and Table 2 for details), with bioburden ranges for the surface swabs (green: $\log _{10}[$ ATP] $<25 \%$ of measured values for cave swabs; yellow: $\log _{10}[$ ATP $]<75$ and $\geq 25 \%$ of measured values for cave swabs; red: $\log _{10}[$ ATP $] \geq 75 \%$ of measured values for cave swabs). Ground plan modified after the Cave Cadastre of the Karst Research Institute at ZRC SAZU. 
Mulec et al., 2013), which is why many surfaces in this cave section, including the tourist footpath, are spattered with bat excrement. Around 6,000 tourists visit Predjama Cave annually. The long-term average precipitation level in the area is $1,578 \mathrm{~mm}$ (Nadbath, 2007).

\section{Swab samples}

Various surfaces that are subjected to microbial colonization were sampled: concrete, flowstone, limestone, metal, and wood (03 November 2015). Each underground sample had an analogue on the surface, except the surfaces subjected to dust contamination from the track of the underground railway, and the tectonically polished surface along an underground fault plane in Postojna Cave. Analogues to the cave samples, from the above-ground environment, were considered if they had a similar composition, e.g. concrete, and if they had suffered comparable environmental impact, e.g. tourist handling (Table 1).

Table 1. Characteristics and locations of sampled surfaces in Postojna and Predjama caves with analogues on the surface.

\begin{tabular}{|c|c|c|c|c|c|}
\hline \multicolumn{3}{|c|}{ Subsurface samples } & \multicolumn{3}{|c|}{ Surface analogues } \\
\hline Location & Substrate & Sample (No.) & Sample (No.) & Substrate & Location \\
\hline Postojna Cave & concrete & tourist footpath (5) & tourist footpath (12) & concrete & Postojna \\
\hline Postojna Cave & flowstone & stalactite $(7)$ & limestone (21) & limestone & Predjama \\
\hline Postojna Cave & flowstone & stalagmite (4) & $\ldots$ & $\ldots$ & $\ldots$ \\
\hline Postojna Cave & flowstone & stalagmite, touched (6) & monument, touched (13) & limestone & Postojna \\
\hline Postojna Cave & limestone & flooding zone, dry (1) & flooding zone, dry (11) & limestone & Postojna \\
\hline Postojna Cave & limestone & cave biofilm (18) & subaerial biofilm (20) & limestone & Predjama \\
\hline Postojna Cave & metal & protection fence (9) & door handle (14) & metal & Postojna \\
\hline Postojna Cave & wood & dead wood (10) & dead wood (17) & wood & Postojna \\
\hline Postojna Cave & wood & railroad tie (3) & railroad tie (15) & wood & Postojna \\
\hline Predjama Cave & limestone & bat guano (19) & pigeon guano (16) & concrete & Postojna \\
\hline Postojna Cave & flowstone & dust (2) & $\ldots$ & $\ldots$ & $\ldots$ \\
\hline Postojna Cave & limestone & tectonic slickenside (8) & $\ldots$ & $\ldots$ & $\ldots$ \\
\hline
\end{tabular}

Surfaces in the show caves were selected to estimate the human impact (e.g. tourist footpaths, stalagmites stained with a brownish patina due to tourist handling, and copper within the safety fences) vs. pristine surfaces. The location sampled at the safety fence is designated as an assembly point for tourist groups, and hence a high human impact (touching) was expected at this site. Surfaces that can provide nutrients and enhance microbial growth (dead wood, wooden railroad ties) were sampled too, as well as those that represent considerable microbial inoculum and biomass for the underground: a surface subjected to regular floods, a rock surface colonized by natural biofilm and exposed to bat droppings, a dusty rock surface along the underground railway, and a tectonically polished surface on an active fault (Šebela et al., 2010) $58 \mathrm{~m}$ beneath the land surface (Table 1). It was demonstrated in a previous study (Šebela $\&$ Mulec, 2011) that heterotrophic aerobic bacteria (cultivated at $37^{\circ} \mathrm{C}$ ) were detected four months after sterilization of this tectonic slickenside on a fault plane (Šebela \& Mulec, 2011). Locations of sampling sites in Postojna Cave are shown in Figure 1.

Surface swab analogues were sampled in Predjama village close to the entrance of Predjama Cave (limestone cliff with subaerial biofilm) and in Postojna (limestone monument in the town centre, door handle at an apartment block, dead wood at the edge of the forest, railroad tie close to Postojna Railway Station and a concrete footpath spattered with pigeon guano). Surfaces spattered with pigeon guano are common in urban environments and, in a similar way to bat guano in caves, they represent a significant source of organic material. Sampling close to the entrance of Postojna Cave included: a footpath near where tourists enter the cave, and limestone rocks in the flooding zone where the Pivka River sinks into the cave (Table 1). To reduce transmission of microbes and organic matter by tourists, a disinfection barrier was introduced at the entrance of Postojna Cave in 2011.

\section{Settled aerosol samples}

The gravity-settling method (Borda et al., 2014) was used to sample airborne biomass in Postojna Cave. Sterilized limestone tablets with a diameter of $41 \mathrm{~mm}$ were exposed to the atmosphere for 34 days, starting on 30 September 2015. Stone tablets were cut from a limestone slab, taken from the homogenous upper Cretaceous Lipica Limestone (Gams, 1985; Mulec \& Prelovšek, 2015). Tablets were placed in various parts of Postojna Cave to observe differences related to the surrounding environmental conditions: presence of sediments (sample No. 22 in Rov starih podpisov), underground train transportation (No. 23 in Stara jama), restricted visitation (No. 24 in Pisani rov, with less than 50 visitors during the study period), and mass tourism (No. 25 in Lepe jame where 55,000 tourists passed by during that period, Fig. 1). A reference tablet (No. 26) was exposed to the external atmosphere in Postojna town centre. After incubation in the cave the tablets were swabbed as described below (Fig. 2).

\section{Water samples}

Three distinctive types of sample were taken in Postojna Cave (03 November 2015): Pivka River after the ponor (No. 100), percolation water from active drips (No. 101 and No. 102) and percolation water captured in a pool with cave pearls (No. 103, Fig. 1). The cave ceiling is 80 to $115 \mathrm{~m}$ thick above the sampling sites with dripping water (Franjo Drole, 


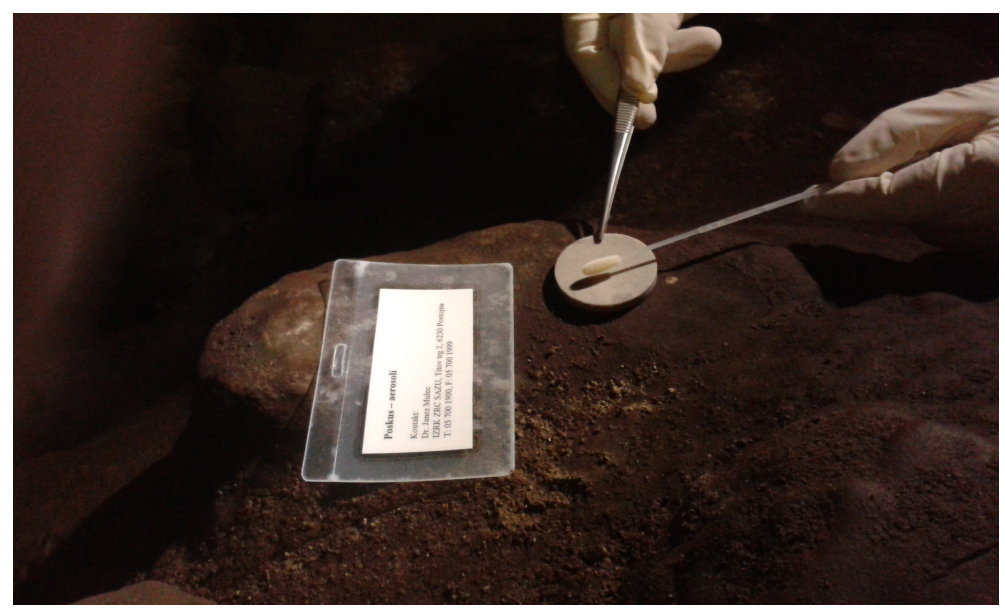

Fig. 2. Swabbing a limestone tablet with a flocked swab after exposure in Postojna Cave.

personal communication). To compare biomass input in the underground karst of the Pivka River, the Lokva River was sampled at the ponor in Predjama Cave (No. 104). pH, temperature, specific electrical conductivity (SEC) and oxygen were measured using a WTW Multi Line P4 (Germany) and a Multi 3420 (Germany), respectively.

\section{Swabbing procedure}

After a surface with minimum irregularities was selected, it was further delimited by a template for bioburden control $(5 \times 4 \mathrm{~cm}$, Copan). Up to three adjacent surfaces $\left(60 \mathrm{~cm}^{2}\right)$ were swabbed (FLOQSwabs $^{\mathrm{TM}}$, Copan) at sites with expected low biomass (Nos. 4, 7, 9, 11, 13, 14, 15, 17). Swabs were transferred in a tube with $1.0 \mathrm{ml}$ of $0.9 \%$ physiological saline. In the laboratory, after vigorous vortexing, $0.8 \mathrm{ml}$ of the saline solution was transferred into a new tube. Swabs in the original tubes were additionally centrifuged for 10 minutes at 4,000 RPM to release any remaining liquid $(\sim 0.1 \mathrm{ml})$. Samples were initially diluted 6-fold, and subsequently diluted serially up to $10^{-3}$. Dilutions were used for ATP measurements and plating on microbiological media. Because of the expected low biomass deriving from settled aerosols, all of the initial liquid $(\sim 0.9 \mathrm{ml})$ was used for the analyses.

\section{Biomass estimation with ATP}

The ATP content of $0.1 \mathrm{ml}$ aliquots was estimated with an AquaSnap ${ }^{\mathrm{TM} T o t a l}$ test using a corresponding luminometer (Hygiena, USA). ATP concentration was expressed as RLU Relative Light Units (where 1 RLU equates to 1 fmol of ATP) and calculated per swabbed surface (RLU / $20 \mathrm{~cm}^{2}$ ).

\section{Biomass of cultivable microbes and identification of coliforms}

Samples with corresponding dilutions were plated onto four different media to propagate microbial colonies: nutrient agar (NA, Fluka), malt extract agar (MEA, Fluka), CF-chromID ${ }^{\mathrm{TM}}$ Coli agar (CF, Biomérieux) and water agar (WA), which contained $1.5 \%$ agar (Biomérieux) and percolation water that was sampled (26 October 2015) from a permanent active drip (discharge during sampling was $1.1 \mathrm{l} / \mathrm{min}$ ) in Planina Cave (Planinska jama). Planina Cave, part of which carries the underground Pivka River downstream of Postojna Cave, has a similar geological setting (Zupančič et al., 2011). WA was designed to mimic natural oligotrophic conditions. The sampled water had the following physicochemical characteristics: $\mathrm{pH} 8.38$, SEC $496 \mu \mathrm{S} / \mathrm{cm}$, temperature $10.6^{\circ} \mathrm{C}$, oxygen 10.76 $\mathrm{mg} / 1(101.7 \%), \mathrm{Cl}^{-} 5.70 \mathrm{mg} / 1, \mathrm{NO}_{3}{ }^{-} 13.73 \mathrm{mg} / 1, \mathrm{SO}_{4}{ }^{2-}$ $3.45 \mathrm{mg} / 1, \mathrm{PO}_{4}{ }^{3-} 0.002 \mathrm{mg} / 1, \mathrm{Ca}^{2+}+\mathrm{Mg}^{2+}$ vs. $\mathrm{Ca}^{2+}$ 1.46 , hardness expressed as $267.8 \mathrm{CaCO}_{3} \mathrm{mg} / 1$ and alkalinity expressed as $276.3 \mathrm{CaCO}_{3} \mathrm{mg} / 1$. The water was analysed using Standard methods (Clesceri et al., 1998). The same set of media (nutrient-rich NA and MEA, and nutrient-poor WA) was used to estimate microbial biomass for all samples subjected to oligotrophic or eutrophic conditions (Table 2).

Petri plates with NA, MEA and WA were cultivated aerobically in Postojna Cave at $10^{\circ} \mathrm{C}$ for 28 days, and in a laboratory at $20^{\circ} \mathrm{C}$ for up to 14 days. Incubation on NA at $20^{\circ} \mathrm{C}$ served to estimate $\mathrm{r}$ - and $\mathrm{K}$-strategists in communities. The general conditions require 3 days to determine $\mathrm{r}$-strategists and an additional 4 to 7 days for K-strategists (Krištůfek et al., 2005). A subset of Petri plates with NA and CF was cultivated aerobically at $37^{\circ} \mathrm{C}$ for 2 days. Visible colonies were quantified in

Table 2. List of sampling methodologies and biomass estimators for different habitats.

\begin{tabular}{|c|c|c|c|}
\hline Habitat & Surface & Air & Water \\
\hline Method & Swabbing & Gravity-settling & Direct intake \\
\hline ATP biomass estimator (units) & $\mathrm{RLU} / 20 \mathrm{~cm}^{2}$ & $\mathrm{RLU} / 20 \mathrm{~cm}^{2} \dagger$ & RLU/ ml \\
\hline Cultivable biomass (units) & $\mathrm{CFU} / 20 \mathrm{~cm}^{2}$ & $\mathrm{CFU} / 20 \mathrm{~cm}^{2} \dagger$ & $\mathrm{CFU} / \mathrm{ml}$ \\
\hline \multirow[t]{8}{*}{ Medium: temperature: time } & NA: $10^{\circ} \mathrm{C}: 28 \mathrm{D}$ & NA: $10^{\circ} \mathrm{C}: 28 \mathrm{D}$ & NA: $10^{\circ} \mathrm{C}: 28 \mathrm{D}$ \\
\hline & WA: $10^{\circ} \mathrm{C}: 28 \mathrm{D}$ & WA: $10^{\circ} \mathrm{C}: 28 \mathrm{D}$ & WA: $10^{\circ} \mathrm{C}: 28 \mathrm{D}$ \\
\hline & MEA: $10^{\circ} \mathrm{C}: 28 \mathrm{D}$ & MEA: $10^{\circ} \mathrm{C}: 28 \mathrm{D}$ & MEA: $10^{\circ} \mathrm{C}: 28 \mathrm{D}$ \\
\hline & NA: $20^{\circ} \mathrm{C}: 3^{*}, 7^{*}, 14 \mathrm{D}$ & NA: $20^{\circ} \mathrm{C}: 3,7,14 \mathrm{D}$ & NA: $20^{\circ} \mathrm{C}: 3,7,14 \mathrm{D}$ \\
\hline & WA: $20^{\circ} \mathrm{C}: 3,7,14 \mathrm{D}$ & WA: $20^{\circ} \mathrm{C}: 3,7,14 \mathrm{D}$ & WA: $20^{\circ} \mathrm{C}: 3,7,14 \mathrm{D}$ \\
\hline & MEA: $20^{\circ} \mathrm{C}: 3,7,14 \mathrm{D}$ & MEA: $20^{\circ} \mathrm{C}: 3,7,14 \mathrm{D}$ & MEA: $20^{\circ} \mathrm{C}: 3,7,14 \mathrm{D}$ \\
\hline & NA: $37^{\circ} \mathrm{C}: 1,2 \mathrm{D}$ & NA: $37^{\circ} \mathrm{C}: 1,2 \mathrm{D}$ & NA: $37^{\circ} \mathrm{C}: 1,2 \mathrm{D}$ \\
\hline & $\mathrm{CF}: 37^{\circ} \mathrm{C}: 1,2 \ddagger \mathrm{D}$ & $\mathrm{CF}: 37^{\circ} \mathrm{C}: 1,2 \mathrm{D}$ & $\mathrm{CF}: 37^{\circ} \mathrm{C}: 1,2 \mathrm{D}$ \\
\hline
\end{tabular}

* - r-/K- strategy; D - day(s) of cultivation; $\dagger-34$ days period of collecting settled aerosols; $\ddagger-$-identification of Enterobacteriaceae with Api®20E 
terms of Colony-Forming-Units (CFU) and calculated as $\mathrm{CFU} / 20 \mathrm{~cm}^{2}$. Colonies that expressed $\beta-\mathrm{D}$ galactosidase enzymatic activity typical for coliforms and $\beta$-D-glucuronidase typical for Escherichia coli on the $\mathrm{CF}$ medium were further confirmed using an Api ${ }^{\circledR} 20 \mathrm{E}$ (Biomérieux) identification scheme. Table 2 summarizes sampling methodologies, biomass estimators, and cultivation media and conditions used in the study.

\section{Statistical analyses}

Statistical analyses were performed using PAST (Hammer et al., 2001) and Daniel's XL Toolbox, an open-source add-in for Microsoft Excel (Version 6.60).

\section{RESULTS}

\section{Biomass of swabs}

Biomass of swabs in terms of ATP was extremely varying, ranging from 240 to $1,258,800 \mathrm{RLU} / 20 \mathrm{~cm}^{2}$ for cave samples, and from 0 to $114,390 \mathrm{RLU} / 20 \mathrm{~cm}^{2}$ for external non-cave environments (Table 3 ). The highest in-cave value was for a stalagmite contaminated by touching $\left(1,258,800 \mathrm{RLU} / 20 \mathrm{~cm}^{2}\right.$, No. 6), followed by dead wood $\left(848,880\right.$ RLU/ $20 \mathrm{~cm}^{2}$ No. 10), a surface with bat guano droppings $\left(750,600\right.$ RLU/ $20 \mathrm{~cm}^{2}$, No. 19) and a tourist footpath $(412,200$ RLU/ $20 \mathrm{~cm}^{2}$, No. 5). The highest biomass level in the external non-cave environment was attributed to occasionally flooded limestone in a riverbed $\left(114,390 \mathrm{RLU} / 20 \mathrm{~cm}^{2}\right.$, No. 11) and rock colonized by biofilm (106,200 RLU/ $20 \mathrm{~cm}^{2}$, No. 20). The lowest biomass on a natural in-cave surface was on a flowstone in an undisturbed part of the cave (900 RLU/ $20 \mathrm{~cm}^{2}$, No. 4). An analogue on the surface expressed a higher bioburden $(17,820$ RLU/ $20 \mathrm{~cm}^{2}$, No. 21). A relatively high value was found on a tectonically polished surface $\left(32,040 \mathrm{RLU} / 20 \mathrm{~cm}^{2}\right.$, No. 8). Biomass occurring as cave and aerial biofilms showed a similar order of environmental bioburden expressed in ATP units. Absence of microbial biomass on a tourist footpath just outside the cave entrance was attributed to the application of a cleaning solution on the day of sampling, although 70 tourists walked along the swabbed surface immediately prior to the sampling.

The highest CFU counts were from a swabbed concrete footpath in the cave, $7.45 \times 10^{6} \mathrm{CFU} / 20$ $\mathrm{cm}^{2}$ (No. 5) on WA medium $\left(20^{\circ} \mathrm{C}\right)$. The same order of microbial concentration on the WA medium was also for a swabbed limestone surface soiled with bat excrement (No. 19), dead wood (No. 10), a stalagmite contaminated by tourist contact (No. 6) and a wooden railroad tie (No. 3). Concentrations of microbial CFU comparable with these samples were also obtained on the NA medium. Using the same method, microbial biomass of the external non-cave surfaces was found to be poorer, with the highest concentration of viable microbes on the WA medium. The highest CFU counts from the external environments were from a swabbed railroad tie, $3.02 \times 10^{4} \mathrm{CFU} / 20 \mathrm{~cm}^{2}$ (No. 15), followed by a limestone subjected to floods (No. 11), a concrete surface with pigeon guano (No. 16) and a limestone with biofilm
(No. 20). MEA that supports fungal growth (Campbell et al., 2013) showed concentrations of cultivable fungi up to three orders of magnitude lower compared to bacteria (Table 3 ).

There was a strong positive correlation between ATP and CFU counts on all media for swabbed surfaces in caves $(\mathrm{n}=12)$, but the statistical significance $(\mathrm{p}<0.05)$ was only for CFU counts on WA medium cultivated at $10^{\circ} \mathrm{C}(\mathrm{r}=0.70, \mathrm{p}=0.012)$ and on MEA medium cultivated at $10^{\circ} \mathrm{C}(\mathrm{r}=0.71, \mathrm{p}=0.01)$. When $\log _{10}$ concentrations of ATP was used in the analysis, statistical significant correlations were obtained also for $\mathrm{CFU}$ counts on NA $\left(10^{\circ} \mathrm{C}, 20^{\circ} \mathrm{C}\right)$ and WA $\left(20^{\circ} \mathrm{C}\right)$. A positive correlation was also apparent between ATP and CFU counts for swabbed surfaces $(n=9)$ from external environments, but the statistical significance was only for CFU counts on NA medium cultivated at $37^{\circ} \mathrm{C}$ (Table 4).

Many samples incubated at $20^{\circ} \mathrm{C}$ expressed higher CFU counts compared to those incubated at cave temperature, except for: a limestone with bat guano (No. 19) and limestone colonized with subaerial biofilm (No. 20) on NA medium, a flowstone with dust (No. 2), a metal safety fence in the cave (No. 9), a limestone subjected to floods (No. 11), a limestone monument handled by the public (No. 13) and external dead wood (No. 17) on WA medium, and on MEA medium for a concrete footpath in the cave (No. 5), limestone with cave biofilm (No. 18), a limestone monument (No. 13), limestone with biofilm (No. 20), and the limestone cliff at Predjama (No. 21, Table 3).

Swabbed microbial communities differed in terms of r-strategists. Microbes that initially colonize a habitat are most commonly r-strategists with the highest growth rates that would favour reproductive success at low population densities, which depends directly on the carrying capacity of the environment (Fontaine et al., 2003; Blagodatskaya \& Kuzyakov, 2008; Ciccazzo et al., 2015). The highest abundance of r-strategists ( $\geq 75 \%$ ) was on dead wood (No. 17), a metal safety fence (No. 9), a limestone with cave biofilm (No. 18), a limestone with fresh bat guano (No. 19), a limestone with biofilm (No. 20) and a stalagmite contaminated by handling (No. 6). The highest microbe abundances in communities growing at $37^{\circ} \mathrm{C}$ compared to those growing at $20^{\circ} \mathrm{C}$ were from a swab from a metal fence (No. 9), a piece of dead wood in the cave (No. 10) and limestone with subaerial biofilm (No. 20). The surface of the dead wood in Postojna Cave was largely impacted by organic and faecal pollution related to the Pivka River. Its swabbed surface contained E.coli (\% ID 98.4, good identification) and Citrobacter youngae (\% ID 77.0\%, good identification to genus).

\section{Airborne biomass}

Cave air carries a significant quantity of dust and diverse microbes (Mulec et al., 2012b; Martin-Sanchez \& Saiz-Jimenez, 2014). An approximately 10-times higher concentration of biomass was retrieved from settled aerosols on a limestone tablet (379 RLU/ $20 \mathrm{~cm}^{2}$ ) in the restricted access part of Postojna Cave (No. 24) during a period of 34 days, compared 


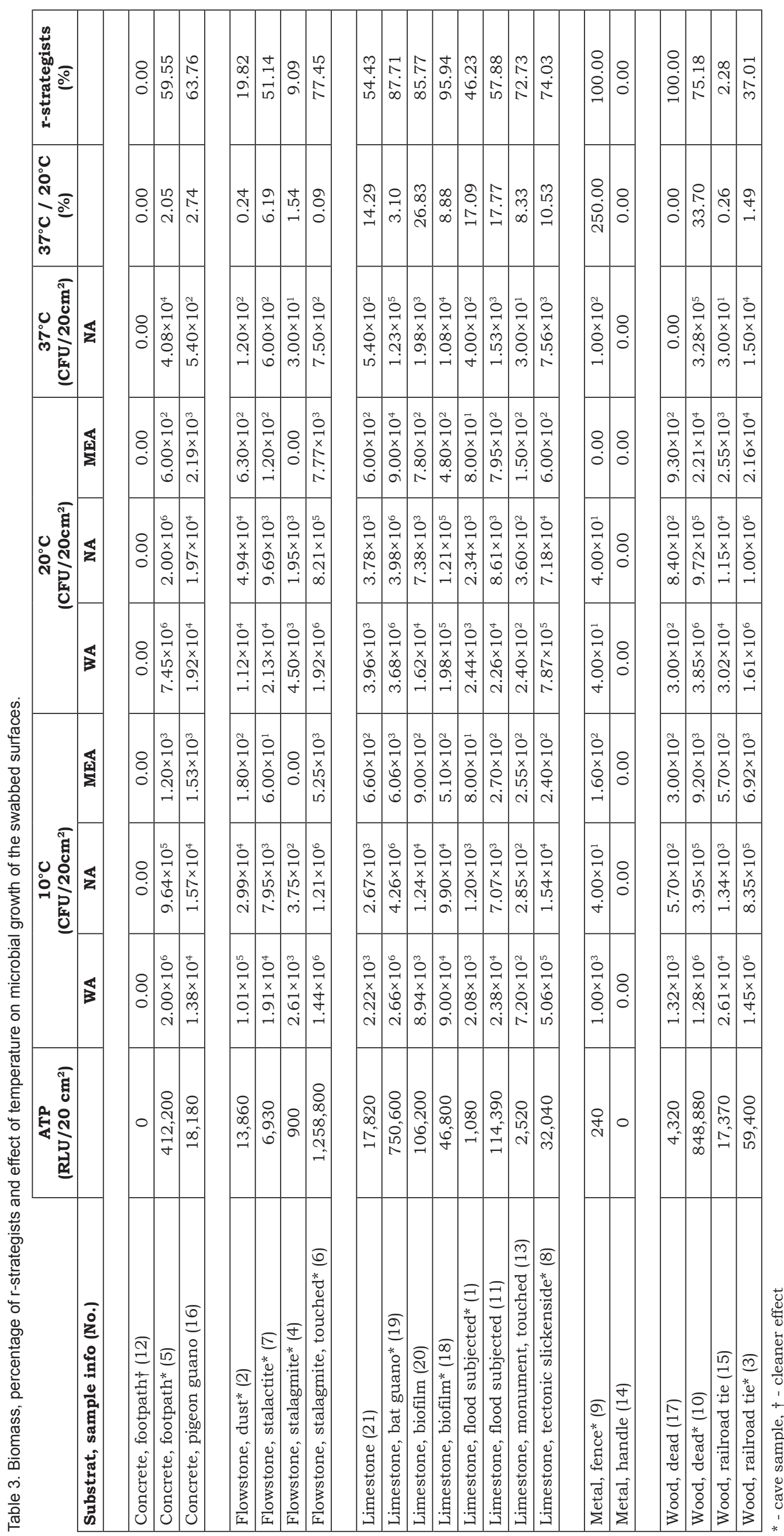


Table 4. Summary of correlations between ATP concentrations and CFU of swabs on different media and cultivation conditions ( $r$ - Pearson's correlation coefficient, $p<0.05$ bold).

\begin{tabular}{|c|c|c|c|c|c|c|c|c|}
\hline \multirow[b]{2}{*}{ ATP estimator } & \multirow[b]{2}{*}{ Environment } & \multicolumn{3}{|c|}{$11^{\circ} \mathrm{C}$} & \multicolumn{3}{|c|}{$20^{\circ} \mathrm{C}$} & \multirow{2}{*}{$\begin{array}{c}37^{\circ} \mathrm{C} \\
\text { NA (r/p) }\end{array}$} \\
\hline & & $N A(r / p)$ & WA (r/p) & $\operatorname{MEA}(\mathbf{r} / \mathbf{p})$ & NA (r/p) & WA (r/p) & MEA $(\mathbf{r} / \mathbf{p})$ & \\
\hline [ATP] & subsurface & $0.56 / 0.056$ & $0.70 / \mathbf{0 . 0 1 2}$ & $0.71 / \mathbf{0 . 0 1 0}$ & $0.56 / 0.061$ & $0.55 / 0.064$ & $0.46 / 0.135$ & $0.52 / 0.081$ \\
\hline $\log _{10}[$ ATP $]$ & subsurface & $0.58 / \mathbf{0 . 0 4 8}$ & $0.82 / \mathbf{0 . 0 0 1}$ & $0.71 / \mathbf{0 . 0 1 0}$ & $0.65 / \mathbf{0 . 0 2 1}$ & $0.71 / \mathbf{0 . 0 1 0}$ & $0.49 / 0.105$ & $0.52 / 0.080$ \\
\hline [ATP] & surface & $0.57 / 0.107$ & $0.53 / 0.139$ & $0.21 / 0.581$ & $0.31 / 0.412$ & $0.55 / 0.125$ & $0.07 / 0.867$ & $0.96 / \mathbf{0 . 0 0 1}$ \\
\hline $\log _{10}[\mathrm{ATP}]$ & surface & $0.61 / 0.146$ & $0.58 / 0.170$ & $0.26 / 0.574$ & $0.43 / 0.332$ & $0.65 / 0.116$ & $0.12 / 0.793$ & $0.90 / \mathbf{0 . 0 0 6}$ \\
\hline
\end{tabular}

to the cave section exposed to dust pollutions from the underground train (No. 23) and the external atmosphere (No. 26). The sampling point along the underground railway (No. 23) is close to the Rov pri Mumiji passage, where a strong air flow is present in the cold season and is also responsible for local air circulation (Mulec et al., 2012b). Cave air close to alluvial sediments, cave biofilms and aerosols partly originating from the Pivka River (No. 22, Fig. 1) had 3,075 RLU/ $20 \mathrm{~cm}^{2}$ (Table 5). The highest recorded biomass during the same period was in the cave air along the tourist footpath, 7,908 RLU/ $20 \mathrm{~cm}^{2}$ (No. 25).

The highest concentration of biomass expressed as ATP (No. 25) did not correspond to the highest concentration of biomass estimated as CFU (Table 5). The highest CFU count ( 200,000 CFU/ $20 \mathrm{~cm}^{2}$ on NA at $10^{\circ} \mathrm{C}$ ) during a period of 34 days was for the settled aerosols in the section of the cave with restricted access. The effect of a temperature shift from 10 to $20^{\circ} \mathrm{C}$ was not clearly expressed in the corresponding increases of $\mathrm{CFU}$ counts. The highest $\mathrm{CFU}$ count at $37^{\circ} \mathrm{C}$ was at the site with cave sediment (No. 22); the high level of this count can also be attributed to settled aerosols that also contained high $\mathrm{CFU}$ at $37^{\circ} \mathrm{C}$ originating from the Pivka River (Table 6).

\section{Biomass in karst waters}

Water samples differed in physicochemical parameters and biomass indicators. Drip water values were below the detection limit or showed very low concentration of biomass, both in terms of ATP and $\mathrm{CFU}$. Ponor rivers bring many viable microbes and abundant organic matter into the underground environment compared to drip water (Table 6). A three-times higher concentration of microbial biomass expressed as ATP for the Pivka River compared to that of the Lokva River was not reflected in all corresponding values of CFU on different media. The Pivka River also deposits faecal microbes on cave surfaces, as was indicated by dead wood surface colonized by E. coli (swab No. 10).

Table 5. Estimated biomass of settled aerosols during 34 days in Postojna Cave.

\begin{tabular}{|c|c|c|c|c|c|c|c|c|}
\hline \multirow[b]{2}{*}{ Aerosol site (No.) } & \multirow[t]{2}{*}{$\begin{array}{c}\text { ATP } \\
\left(\mathrm{RLU} / 20 \mathrm{~cm}^{2}\right)\end{array}$} & \multicolumn{3}{|c|}{$\begin{array}{c}10^{\circ} \mathrm{C} \\
\left(\mathrm{CFU} / 20 \mathrm{~cm}^{2}\right)\end{array}$} & \multicolumn{3}{|c|}{$\begin{array}{c}20^{\circ} \mathrm{C} \\
\left(\mathrm{CFU} / 20 \mathrm{~cm}^{2}\right)\end{array}$} & \multirow{2}{*}{$\begin{array}{c}37^{\circ} \mathrm{C} \\
\left(\mathrm{CFU} / 20 \mathrm{~cm}^{2}\right) \\
\text { NA }\end{array}$} \\
\hline & & WA & NA & MEA & WA & NA & MEA & \\
\hline Cave sediment (No. 22) & 3,075 & $96,375^{*}$ & $38,550^{*}$ & 470 & 95,421 & 24,101 & 470 & 163,831 \\
\hline Train dusting (No. 23) & 30 & 2,197 & 2,560 & 136 & 2,606 & 2,863 & 303 & 167 \\
\hline Visitors restricted (No. 24) & 379 & 11,028 & $192,751^{*}$ & 30 & 42,795 & 57,822 & 15 & 1,409 \\
\hline Tourist visits (No. 25) & 7,908 & $48,188^{*}$ & $77,100^{*}$ & 1,636 & 82,878 & 67,457 & 3,939 & 57,928 \\
\hline External control (No. 26) & 15 & 15 & 30 & 15 & 30 & 30 & 0 & 0 \\
\hline
\end{tabular}

* - estimated

Table 6. Physico-chemical conditions and comparison of microbial biomass in different water bodies

\begin{tabular}{|c|c|c|c|c|c|c|c|c|c|c|c|c|}
\hline \multirow[b]{2}{*}{ Sample (No.) } & \multirow[t]{2}{*}{$\begin{array}{c}\text { Temp. } \\
\left({ }^{\circ} \mathrm{C}\right)\end{array}$} & \multirow[t]{2}{*}{\begin{tabular}{|c|} 
SEC \\
$(\mu \mathrm{S} / \mathrm{cm})$
\end{tabular}} & \multirow[t]{2}{*}{ pH } & \multirow[t]{2}{*}{$\begin{array}{c}\text { Oxygen } \\
\text { (mg/1) }\end{array}$} & \multirow[t]{2}{*}{$\begin{array}{c}\text { ATP } \\
\text { (RLU/ml) }\end{array}$} & \multicolumn{3}{|c|}{$\begin{array}{c}10^{\circ} \mathrm{C} \\
(\mathrm{CFU} / \mathrm{ml})\end{array}$} & \multicolumn{3}{|c|}{$\begin{array}{c}20^{\circ} \mathrm{C} \\
(\mathrm{CFU} / \mathrm{ml})\end{array}$} & \multirow{2}{*}{$\begin{array}{c}\begin{array}{c}37^{\circ} \mathrm{C} \\
(\mathrm{CFU} / \mathrm{ml})\end{array} \\
\text { NA }\end{array}$} \\
\hline & & & & & & WA & NA & MEA & WA & NA & MEA & \\
\hline Drip (101)† & 11.8 & 452 & 8.22 & 10.47 & 0 & 0 & 0 & 0 & 0 & 0 & 0 & 0 \\
\hline Drip (102)‡ & 10.2 & 276 & 8.37 & 10.90 & 10 & 40 & 0 & 0 & 0 & 0 & 0 & 0 \\
\hline Pool water (103) & 10.1 & 320 & 8.60 & 10.87 & 10 & 120 & 40 & 10 & 130 & 50 & 0 & 10 \\
\hline River, Lokva (104) & 5.3 & 298 & 8.33 & 12.46 & 630 & 4,990 & 3,175 & 40 & 14,100 & 3,535 & 290 & 840 \\
\hline River, Pivka (100) & 7.0 & 413 & 7.98 & 9.52 & 1,925 & 12,300 & 890 & 365 & 14,700 & 1,980 & 70 & 395 \\
\hline
\end{tabular}

$\dagger$ - drip rate: $0.65 \mathrm{ml} / \mathrm{s}$; - drip rate: $0.67 \mathrm{ml} / \mathrm{s}$

\section{DISCUSSION}

\section{Surface and subsurface biomass}

Not all microbial colonization attempts are (completely) successful, because of unsuitable surface conditions (Kargar et al., 2014). In a continuous flow of allochthonous organic matter in karst, the new-coming microbes play a significant role in the colonization-succession process (Barton et al., 2013; Brannen-Donnelly \& Engel, 2015). A relative high input of biomass in the underground karst occurs in well-fissured areas, as was demonstrated on a tectonically polished surface of an active fault plane inside Postojna Cave in this and a previous 
study (Šebela \& Mulec, 2011). A high percentage of r-strategists $(74.03 \%)$ and microbes able to grow at $37^{\circ} \mathrm{C}$ were detected at this site (Table 3). Rapidly growing r-strategists commonly dominate in uncrowded and unstable habitats where resources are temporarily abundant (Andrews \& Harris, 2013). Low abundances of r-strategists were found on external (2.28\%, No. 15) and in-cave wooden railroad ties $(37.01 \%$, No. 1), an untouched and pristine stalagmite $(9.09 \%$, No. 4$)$, and in dust associated with the underground railway $(19.82 \%$, No. 2). Dust particles collected along the main passage in Postojna Cave contained increased concentration of heavy metals, $\mathrm{Cu}, \mathrm{Pb}, \mathrm{Zn}, \mathrm{Fe}$ and $\mathrm{Mn}$ (Muri et al., 2013), which can adversely affect microbes and their metabolism processes (Giller et al., 1998).

Different media and cultivation conditions resulted in different numbers of $\mathrm{CFU}$, which also gave distinct correlations between total biomass estimator - ATP and counted colonies. Particularly for the cave samples, stronger correlations were observed for samples cultivated at the cave temperature rather than at $20^{\circ} \mathrm{C}$ (Table 4). A stronger correlation between ATP and $\mathrm{CFU}$ plate counts at low cultivation temperature $\left(10^{\circ} \mathrm{C}\right.$ vs. $35^{\circ} \mathrm{C}$ ) has already been established for bacteria from cold environments, for example refrigerators (Chen \& Godwin, 2006). Interestingly, a very strong relationship between ATP and CFU on NA $\left(37^{\circ} \mathrm{C}\right)$ for above-ground samples was observed, but this cultivation condition enabled growth only of a small proportion of the microbial community (Table 3). In the study, anaerobic plate count was not evaluated because only a smaller portion of the microbial community may be attributed to strict anaerobes, because all the sampling sites were exposed to normal oxygen concentrations.

Results of the study indicate that underground microclimatic conditions might play an important role in the preservation or even the concentration of nonviable microbial biomass and viable microorganisms. This is especially the case for big cave systems that intercept a karst massif subject to high levels of precipitation, which accelerate the transport of organic matter and microbes. A microbial community colonizing cave surfaces can produce a notable influence on the cave ecology. Surfaces contaminated with animal excrement, e.g. from bats (Mulec et al., 2012a) and the presence of visible microbial biofilms (Mulec et al., 2015) are important sources of microbial biomass (Table 3) in the underground. Some caves do not rely only upon the input of organic matter from the surface, but are characterized by in situ microbial biomass production based on chemoautotrophic metabolism (Jones \& Macalady, 2016). For example, a metagenomic analysis of surface speleothems from Kartchner Cavern, located in an arid zone (Arizona, USA) revealed the presence of a chemoautotrophic community adapted to low-nutrient conditions (Ortiz et al., 2014). In chemoautotrophy-based cave ecosystems, e.g. Frasassi Cave, Italy, in situ low nitrogen can be surmounted by a diazotrophy (Desai et al., 2013).
Areas where aerosols settle provide high bioburden potential for the cave (Table 5). Locally there are major differences in the sampled presence of organic matter, which can also be explained by the low percentage of r-strategists - for example on a swabbed stalagmite (900 RLU/ $20 \mathrm{~cm}^{2}$, No. 4). Interestingly, at the same location (Fig. 1), in only 34 days the settled aerosols showed a rather high biomass (379 RLU/ $20 \mathrm{~cm}^{2}$, No. 24, Table 5), which can be attributed to the circulation of biomass-rich air masses in the cave across longer distances. As well as through the movements of air masses, microbes enter caves with both flowing and seeping water, as well as with animals and humans (Mulec, 2015). Not just the major flows of ponor rivers, but also dispersed epikarstic seepage water bring along considerable amounts of organic carbon (Simon et al., 2007).

In comparison to UltraSnap ${ }^{\mathrm{TM}}$ (data not shown), which basically consists of cotton swabs, AquaSnap ${ }^{\mathrm{TM}}$ Total, when used in combination with flocked swabs (FLOQSwabs ${ }^{\mathrm{TM}}$ ) as an ATP biomass estimator tool, showed correlations with CFU counts and thus considerable promise for determination of the microbial biomass in various cave sub-habitats. UltraSnap $^{\mathrm{TM}}$ kit has previously been used for surface swabbing in Lechuguilla Cave (New Mexico, USA), where the DAPI total cell count did not change significantly in line with changes in ATP levels (Johnston, 2013). In a previous study in Postojna Cave (Mulec et al., 2012a), similar surfaces were swabbed using RIDA®COUNT test plates directly for swabbing. The swabbing procedure described in this study and the use of comparable nutrientrich media (NA vs. RIDA $® C O U N T$ Total for bacteria and MEA vs. RIDA ${ }^{\circ}$ COUNT Yeast\&Mold Rapid for fungi), with similar cultivation conditions $\left(35^{\circ} \mathrm{C}\right.$ and $37^{\circ} \mathrm{C}$ for 48 hours for bacteria, $20^{\circ} \mathrm{C}$ for 72 hours for fungi) resulted in 3-times up to 80-times higher $\mathrm{CFU}$ retrieval. However, more data collection is needed to help develop this procedure as a general estimator for the bioburden of underground habitats. An example of bioburden ranges for Postojna Cave, based upon the ATP levels of swab samples is given in Fig. 1. An ATP biomass estimator (AquaSnap ${ }^{\mathrm{TM}}$ Total) can be used as the first and easiest step in studying factors that affect microbial transport and colonization underground.

\section{Human impact in show caves}

Karst caves and karst aquifers are highly susceptible to pollution and biomass input from various sources such as wastewater discharge, agricultural and urban run-off (Mahler et al., 2000; Reed et al., 2011), and tourism (Jurado et al., 2014; Mulec, 2014). Locally high concentrations of biomass in Postojna Cave are related to human activities (Fig. 1). Based on biomass estimates recorded during this study, Postojna Cave seems to be mainly affected by human intervention that is attributed to the surface biomass of wooden railroad ties $\left(\sim 1.30 \times 10^{11}\right.$ RLU of ATP, $\sim 3.50 \times 10^{12}$ CFU) and tourist footpaths $\left(\sim 7.80 \times 10^{11}\right.$ RLU of ATP, $\left.\sim 1.41 \times 10^{13} \mathrm{CFU}\right)$. In comparison to the Postojna Cave system as a whole, this surface bioburden can represent up to a 1.6-times greater biomass in 
terms of ATP or 6.4-times in terms of CFU, when a standardized bioburden of 900 ATP RLU/ $20 \mathrm{~cm}^{2}$ and $4.50 \times 10^{3} \mathrm{CFU} / 20 \mathrm{~cm}^{2}$ (Table 3, No. 4 as a reference site) is adopted for the entirety of the surveyed cave surfaces, comprising wall and floor areas but excluding isolated speleothems.

The absence both of UV radiation and desiccating conditions in caves results in the survival of microbes from organic pollution, for example Enterobacteriaceae (Campbell et al., 2011). Enterobacteriaceae, more specifically E. coli and Citrobacter, were retrieved from an occasionally flooded surface in Postojna Cave. These two organisms are particularly relevant in the environment as a source of antibiotic resistance determinants that can spread quickly among different species through horizontal gene transfer (Mulec et al., 2002; Perry et al., 2014). It seems that cave conditions (high humidity, presence of sediments and organic debris) enable longer survival of these bacteria. However, in the long term, survival of enterobacteria in aquatic environments is known to be briefer than their survival in soils (McFeters et al., 1974).

The highest ATP value in the study, recorded from a handled speleothem, can also be attributed to epithelium cells from human skin with an average value inside a human cell of between 3 and $5 \mathrm{mM}$ (Gribble et al., 2000). More so, ATP is also present in extracellular compartments where it operates in cell-to-cell signal transduction (Hayashi et al., 2004). High biomass in terms of ATP for this sample was accompanied by a high percentage of $r$-strategists $(77.45 \%)$ and low percentage of microbes able to grow at $37^{\circ} \mathrm{C}$ compared to at $20^{\circ} \mathrm{C}$ (Table 3). Nonetheless, human-derived biomass consequently becomes available for exploitation by cave biota.

Application of a cleaning product on walking surfaces, and use of a disinfecting barrier at the cave entrance contribute to the overall reduction of microbial biomass by tourist footprints, though related levels still remain high in the cave (Fig. 1). The low ATP concentration of a swab on a safety fence in the cave (240 RLU/ $20 \mathrm{~cm}^{2}$, No. 9) can be attributed to the known toxic effect of copper on biota (Baker et al., 2014), even though the sampling site suffers heavy contamination as a result of tourist contact. Copper surfaces are significantly effective in lowering the bioburden (Schmidt et al., 2015). Heavy metals introduced as a part of the tourist infrastructure, e.g. copper within safety fences, metal particles deriving from the railway, particles from the wear and corrosion of the railway tracks (Muri et al., 2013) very likely have an adverse effect on microbiota.

The direct tourist impact in Postojna Cave is not only evident on contact surfaces, but also in the air quality (Mulec et al., 2012b). Whereas one might expect one of the highest levels of biomass in the air to be along the main passage, with the tourist railway, in the cave, this was not the case. Human-induced and natural air streaming direct the movement and settling of aerosols. This can explain the relatively low biomass along the route of the tourist railway (dilution) and the relatively high biomass accumulation in the part of the cave with restricted access.

\section{CONCLUSIONS}

ATP luminescence assay (Hygiena, USA) was tested successfully on different samples. Using flocked swabs (FLOQSwabs ${ }^{\mathrm{TM}}$, Copan) the assay proved its versatility in estimating the bioburden of solid surfaces. Surfaces inside caves displayed similar or even higher levels of bioburden than surfaces exposed to the external atmosphere that can be attributed partly to human impacts. There is a high variability of surface microbial biomass within single cave systems. These cave subhabitats are colonized by physiologically different microbial communities. The highest in-cave values of ATP and CFU from swabbed surfaces were from a stalagmite contaminated by touching, bat guano and tourists' footprints. These samples exhibited also high percentages of $r$-strategists in a community, whereas wood surfaces and untouched pristine stalagmite exhibited low abundances of fast growing bacteria. Not only microbial ATP, but also ATP deriving from human epithelium cells contributed to the highest concentration of ATP from a handled stalagmite. The toxic effect of copper in the metal safety fence can be attributed to low total biomass. A strong positive correlation was recognized between ATP and CFU for swabbed surfaces from caves. Enterobacteriaceae were easy to retrieve from a surface exposed to the underground river, which was contaminated by faecal bacteria. Mass visitation in the tourist part of Postojna Cave resulted in an increased microbial airborne biomass. Microbial biomass on non-cave surface analogues was generally lower.

\section{ACKNOWLEDGEMENTS}

The study was supported by the Slovenian Research Agency (L1-5453, J7-7100). The authors acknowledge Mateja Zadel, Franjo Drole, Miran Bergoč and Edi Šibenik for facility support, and David Lowe for language editing assistance.

\section{REFERENCES}

Andrews J. \& Harris R., 2013 - r-and K-selection and microbial ecology. In: Marshall K. (Ed.), Advances in microbial ecology. Springer, New York, p. 99-147.

Baker T., Tyler C. \& Galloway T., 2014 - Impacts of metal and metal oxide nanoparticles on marine organisms. Environmental Pollution, 186: 257-271.

http://dx.doi.org/10.1016/j.envpol.2013.11.014

Balkwill D., Murphy E., Fair D., Ringelberg D. \& White D., 1998 - Microbial communities in high and low recharge environments: Implications for microbial transport in the vadose zone. Microbial Ecology, 35: 156-171. http://dx.doi.org/10.1007/s002489900070

Barnard R., Osborne C. \& Firestone M., 2013 - Responses of soil bacterial and fungal communities to extreme desiccation and rewetting. ISME Journal, 7: 2229-2241. http://dx.doi.org/10.1038/ismej.2013.104

Barton H., Giarrizzo J., Suarez P., Robertson C., Broering M., Banks E., Vaishampayan P. \& Venkateswaran K., 2014 - Microbial diversity in a Venezuelan orthoquartzite cave is dominated by the Chloroflexi (Class Ktedonobacterales) and Thaumarchaeota Group I.1c. Frontiers in Microbiology, 5: 615. http://dx.doi.org/10.3389/fmicb.2014.00615 
Barton P., Cunningham S., Lindenmayer D. \& Manning A., 2013 - The role of carrion in maintaining biodiversity and ecological processes in terrestrial ecosystems. Oecologia, 171: 761-772.

http://dx.doi.org/10.1007/s00442-012-2460-3

Blagodatskaya E. \& Kuzyakov Y., 2008 - Mechanisms of real and apparent priming effects and their dependence on soil microbial biomass and community structure: critical review. Biology and Fertility of Soils, 45: 115-131.

http://dx.doi.org/10.1007/s00374-008-0334-y

Borda D., Năstase-Bucur R., Spînu M., Uricariu R. \& Mulec J., 2014 - Aerosolized microbes from organic rich materials: case study of bat guano from caves in Romania. Journal of Cave and Karst Studies, 76: 114-126. http://dx.doi.org/10.4311/2013MB0116

Botos I., Majdalani N., Mayclin S.J., McCarthy J.G., Lundquist K., Wojtowicz D., Barnard T.J., Gumbart J.C. \& Buchanan S.K., 2016 - Structural and functional characterization of the LPS transporter LptDE from Gram-negative pathogens. Structure, 24 (6): 965-976. http://dx.doi.org/10.1016/j.str.2016.03.026

Brannen-Donnelly K. \& Engel A., 2015 - Bacterial diversity differences along an epigenic cave stream reveal evidence of community dynamics, succession, and stability. Frontiers in Microbiology, 6: 729. http://dx.doi.org/10.3389/fmicb.2015.00729

Bull A., Ward A. \& Goodfellow M., 2000 - Search and discovery strategies for biotechnology: The paradigm shift. Microbiology and Molecular Biology Reviews, 64: 573-606.

http://dx.doi.org/ 10.1128/MMBR.64.3.573-606.2000

Campbell C., Johnson E. \& Warnock D., 2013 Identification of pathogenic fungi. Wiley-Blackwell, Chichester, $352 \mathrm{p}$.

Campbell J., Watson A., Watson C., Ball H. \& Pirkle R., 2011 - Escherichia coli, other coliform, and environmental chemoheterotrophic bacteria in isolated water pools from six caves in northern Alabama and northwestern Georgia. Journal of Cave and Karst Studies, 73: 75-82.

http://dx.doi.org/10.4311/jcks2009mb0131

Chen F. \& Godwin S., 2006 - Comparison of a rapid ATP bioluminescence assay and standard plate count methods for assessing microbial contamination of consumers' refrigerators. Journal of Food Protection, 69: 2534-2538.

Ciccazzo S., Esposito A., Borruso L. \& Brusetti L., 2015 - Microbial communities and primary succession in high altitude mountain environments. Annals of Microbiology, 66 (1): 43-60.

http://dx.doi.org/10.1007/s13213-015-1130-1

Clesceri L.S., Greenberg A.E. \& Eaton A.D., 1998 - Standard methods for the examination of water and wastewater $\left(20^{\text {th }}\right.$ ed.). American Public Health Association, Washington, D.C., 1325 p.

Cragg A.B. \& Parkes R.J., 2014 - Bacterial and Archaeal direct counts: A faster method of enumeration, for enrichment cultures and aqueous environmental samples. Journal of Microbiological Methods, 98: 35-40. http://dx.doi.org/10.1016/j.mimet.2013.12.006

Čar J. \& Šebela S., 2001 - Karst characteristics of thrust contact limestone-dolomite near Predjama. Acta carsologica, 30: 141-156.

De Roy K., Clement L., Thas O., Wang Y. \& Boon N., 2012 - Flow cytometry for fast microbial community fingerprinting. Water Research, 46: 907-919.

http://dx.doi.org/10.1016/j.watres.2011.11.076
Desai M.S., Assig K. \& Dattagupta S., 2013 - Nitrogen fixation in distinct microbial niches within a chemoautotrophy-driven cave ecosystem. The ISME Journal, 7: 2411-2423.

http://dx.doi.org/10.1038/ismej.2013.126

Fontaine S., Mariotti A. \& Abbadie L., 2003 - The priming effect of organic matter: a question of microbial competition? Soil Biology \& Biochemistry, 35: 837-843. http://dx.doi.org/10.1016/S0038-0717(03)00123-8

Ford D. \& Williams P.W., 2007 - Karst hydrogeology and geomorphology. John Wiley, Chichester, 562 p. http://dx.doi.org/10.1002/9781118684986

Friman V., Jousset A. \& Buckling A., 2014 - Rapid prey evolution can alter the structure of predator-prey communities. Journal of Evolutionary Biology, 27: 374-380. http://dx.doi.org/10.1111/jeb.12303

Gams I., 1985 - International comparative measurements of surface solution by means of standard limestone tablets. Dissertationes/Academia scientiarum et artium Slovenica, Classis IV: Historia naturalis, 26: 361-386.

Giller K., Witter E. \& McGrath S., 1998 - Toxicity of heavy metals to microorganisms and microbial processes in agricultural soils: A review. Soil Biology \& Biochemistry, 30: 1389-1414.

http://dx.doi.org/10.1016/S0038-0717(97)00270-8

Giovannoni S. \& Stingl U., 2007 - The importance of culturing bacterioplankton in the 'omics' age. Nature Reviews Microbiology, 5: 820-826.

http://dx.doi.org/10.1038/nrmicro1752

Gottschalk G., 2012 - Bacterial metabolism (2 $2^{\text {nd }}$ ed.). Springer, Berlin, 341 p.

Gribble F., Loussouarn G., Tucker S., Zhao C., Nichols C. $\&$ Ashcroft F., 2000 - Novel method for measurement of submembrane ATP concentration. Journal of Biological Chemistry, 275: 30046-30049.

http://dx.doi.org/10.1074/jbc.M001010200

Guerrero R., Piqueras M. \& Berlanga M., 2002 Microbial mats and the search for minimal ecosystems. International Microbiology, 5: 177-188. http://dx.doi.org/10.1007/s10123-002-0094-8

Hamasaki K., Taniguchi A., Tada Y., Kaneko R. \& Miki T., 2016 - Active populations of rare microbes in oceanic environments as revealed by bromodeoxyuridine incorporation and $454 \mathrm{tag}$ sequencing. Gene, 576 (2): 650-656. http://dx.doi.org/10.1016/j.gene.2015.10.016

Hammer Ø., Harper D.A.T. \& Ryan P.D., 2001 - PAST: Paleontological statistics software package for education and data analysis. Palaeontologia Electronica, 4: 1-9.

Hammes F., Goldschmidt F., Vital M., Wang Y. \& Egli T., 2010 - Measurement and interpretation of microbial adenosine tri-phosphate (ATP) in aquatic environments. Water Research, 44: 3915-3923.

http://dx.doi.org/10.1016/j.watres.2010.04.015

Hauer T., Mühlsteinová R., Bohunická M., Kaštovský J. \& Mareš J., 2015 - Diversity of cyanobacteria on rock surfaces. Biodiversity and Conservation, 24: 759-779. http://dx.doi.org/10.1007/s10531-015-0890-Z

Hayashi S., Hazama A., Dutta A.K., Sabirov R.Z. \& Okada Y., 2004 - Detecting ATP release by a biosensor method. Science Signaling, 258: pl14. http://dx.doi.org/10.1126/stke.2582004pl14

Johnston M., 2013 - The dominance of the archaea in the terrestrial subsurface. The University of Akron, Akron, $48 \mathrm{p}$.

Jones D.S. \& Macalady J.L., 2016 - The snotty and the stringy: energy for subsurface life in caves. In: Hurst C.J (Ed.), Their world: A diversity of microbial environments. Springer International Publishing, p. 203-224. http://dx.doi.org/10.1007/978-3-319-28071-4 5 
Jurado V., Laiz L., Sanchez-Moral S. \& Saiz-Jimenez C., 2014 - Pathogenic microorganisms related to human visits in Altamira Cave, Spain. In: Saiz-Himenez C. (Ed.), The conservation of subterranean cultural heritage. CRC Press, Leiden, p. 229-239. http://dx.doi.org/10.1201/b17570-28

Kargar M., Pruden A. \& Ducker W., 2014 - Preventing bacterial colonization using colloidal crystals. Journal of Materials Chemistry B, 2: 5962-5971. http://dx.doi.org/10.1039/C4TB00835A

Karl D., 1993 - Total microbial biomass estimation derived from the measurement of participate adenosine5'-triphosphate. In: Kemp P., Sherr B., Sherr E. \& Cole J. (Eds.), Handbook of methods in aquatic microbial ecology. Lewis Publisher, Boca Raton, p. 359-368.

Krištůfek V., Elhottová D., Chroňáková A., Dostálková I., Picek T. \& Kalčík J., 2005 - Growth strategy of heterotrophic bacterial population along successional sequence on spoil of brown coal colliery substrate. Folia Microbiologica, 50: 427-435.

http://dx.doi.org/10.1007/BF02931425

Mahler B., Personne J., Lods G. \& Drogue C., 2000 Transport of free and particulate-associated bacteria in karst. Journal of Hydrology, 238: 179-193. http://dx.doi.org/10.1016/S0022-1694(00)00324-3

Martin-Sanchez P. \& Saiz-Jimenez C., 2014 - Contribution of culture-independent methods to cave aerobiology: The case of Lascaux Cave. In: Saiz-Jimenez C. (Ed.), The conservation of subterranean cultural heritage. CRC Press, Leiden, p. 215-222. http://dx.doi.org/10.1201/b17570-26

McFeters G., Bissonne G., Jezeski J., Thomson C. \& Stuart D., 1974 - Comparative survival of indicator bacteria and enteric pathogens in well water. Applied Microbiology, 27: 823-829.

Morris C., Sands D., Bardin M., Jaenicke R., Vogel B., Leyronas C., Ariya P. \& Psenner R., 2011 - Microbiology and atmospheric processes: research challenges concerning the impact of airborne micro-organisms on the atmosphere and climate. Biogeosciences, 8: 17-25. http://dx.doi.org/10.5194/bg-8-17-2011

Mulec J., Starčič M. \& Žgur-Bertok D., 2002 - F-like plasmid sequences in enteric bacteria of diverse origin, with implication of horizontal transfer and plasmid host range. Current Microbiology, 44: 231-235. http://dx.doi.org/10.1007/s00284-001-0039-7

Mulec J., Krištůfek V. \& Chroňáková A., 2012a Comparative microbial sampling from eutrophic caves in Slovenia and Slovakia using RIDA®COUNT test kits. International Journal of Speleology, 41 (1): 1-8. http://dx.doi.org/10.5038/1827-806X.41.1.1

Mulec J., Vaupotič J. \& Walochnik J., 2012b - Prokaryotic and eukaryotic airborne microorganisms as tracers of microclimatic changes in the underground (Postojna Cave, Slovenia). Microbial Ecology, 64: 654-667. http://dx.doi.org/10.1007/s00248-012-0059-1

Mulec J., Covington E. \& Walochnik J., 2013 - Is bat guano a reservoir of Geomyces destructans? Open Journal of Veterinary Medicine, 3: 161-167.

Mulec J., 2014 - Human impact on underground cultural and natural heritage sites, biological parameters of monitoring and remediation actions for insensitive surfaces: Case of Slovenian show caves. Journal for Nature Conservation, 22: 132-141. http://dx.doi.org/10.1016/j.jnc.2013.10.001

Mulec J., 2015 - The diversity and ecology of microbes associated with lampenflora in cave and karst settings. In: Summers Engel A. (Ed.), Microbial life of cave systems. De Gruyter, Berlin, p. 263-278.

http://dx.doi.org/10.1515/9783110339888-014
Mulec J., Oarga-Mulec A., Tomazin R. \& Matos T., 2015 - Characterization and fluorescence of yellow biofilms in karst caves, southwest Slovenia. International Journal of Speleology, 44 (2): 107-114.

http://dx.doi.org/10.5038/1827-806X.44.2.1

Mulec J. \& Prelovšek M., 2015 - Freshwater biodissolution rates of limestone in the temperate climate of the Dinaric karst in Slovenia. Geomorphology, 228: 787-795. http://dx.doi.org/10.1016/j.geomorph.2014.10.022

Muri G., Jovičić A. \& Mihevc A., 2013 - Source assessment of deposited particles in a Slovenian show cave (Postojnska jama): evidence of long-lasting anthropogenic impact. International Journal of Speleology, 42 (3): 225-233. http://dx.doi.org/10.5038/1827-806X.42.3.6

Musat N., Foster R., Vagner T., Adam B. \& Kuypers M., 2012 - Detecting metabolic activities in single cells, with emphasis on nanoSIMS. FEMS Microbiology Reviews, 36: 486-511.

http://dx.doi.org/10.1111/j.1574-6976.2011.00303.x

Nadbath M., 2007 - Meteorological station Postojna. Mesečni bilten ARSO, 14: 48-53.

Norland S., 1993 - The relationship between biomass and volume of bacteria. In: Kemp P., Sherr B., Sherr E. \& Cole J. (Eds.), Handbook of methods in aquatic microbial ecology. Lewis Publishers, Boca Raton, p. 303-307.

Okibe N. \& Johnson D., 2011 - A rapid ATP-based method for determining active microbial populations in mineral leach liquors. Hydrometallurgy, 108: 195-198. http://dx.doi.org/10.1016/j.hydromet.2011.04.008

Ortiz M., Legatzki A., Neilson J., Fryslie B., Nelson W., Wing R., Soderlund C., Pryor B. \& Maier R., 2014 Making a living while starving in the dark: metagenomic insights into the energy dynamics of a carbonate cave. The ISME Journal, 8: 478-491. http://dx.doi.org/10.1038/ismej.2013.159

Parker J., Smith G., Fredrickson H., Vestal J. \& White D., 1982 - Sensitive assay, based on hydroxy fattyacids from lipopolysaccharide lipid A, for gram-negative bacteria in sediments. Applied and Environmental Microbiology, 44: 1170-1177.

Perry J., Westman E. \& Wright G., 2014 - The antibiotic resistome: what's new? Current Opinion in Microbiology, 21: 45-50.

http://dx.doi.org/10.1016/j.mib.2014.09.002

Presetnik P., Koselj K., Zagmajster M., Aupič N., Jazbec K., Žibrat U., Petrinjak A. \& Hudoklin A., 2009 - Atlas netopirjev (Chiroptera) Slovenije. Center za kartografijo favne in flore, Miklavž na Dravskem polju, $151 \mathrm{p}$.

Pronk M., Goldscheider N. \& Zopfi J., 2006 - Dynamics and interaction of organic carbon, turbidity and bacteria in a karst aquifer system. Hydrogeology Journal, 14: 473-484.

http://dx.doi.org/10.1007/s10040-005-0454-5

Reed T., Fryar A., Brion G. \& Ward J., 2011 - Differences in pathogen indicators between proximal urban and rural karst springs, Central Kentucky, USA. Environmental Earth Sciences, 64: 47-55. http://dx.doi.org/10.1007/s12665-010-0816-8

Röling W. \& van Bodegom P., 2014 - Toward quantitative understanding on microbial community structure and functioning: a modeling-centered approach using degradation of marine oil spills as example. Frontiers in Microbiology, 5: 125.

Schimel J., Balser T. \& Wallenstein M., 2007 - Microbial stress-response physiology and its implications for ecosystem function. Ecology, 88: 1386-1394.

http://dx.doi.org/10.1890/06-0219 
Schmidt M.G., von Dessauer B., Benavente C., Benadof D., Cifuentes P., Elgueta A., Duran C. \& Navarrete M.S., 2016 - Copper surfaces are associated with significantly lower concentrations of bacteria on selected surfaces within a pediatric intensive care unit. American Journal of Infection Control, 44 (2): 203-209.

http://dx.doi.org/10.1016/j.ajic.2015.09.008

Senjarini K., Karsten U. \& Schumann R., 2013 Application of fluorescence markers for the diagnosis of bacterial abundance and viability in aquatic ecosystem. Journal of Microbiology Research, 3: 143-147.

Sgier L., Freimann R., Zupanic A. \& Kroll A., 2016 Flow cytometry combined with viSNE for the analysis of microbial biofilms and detection of microplastics. Nature Communications, 7: 11587. http://dx.doi.org/10.1038/ncomms 11587

Simon K., Pipan T. \& Culver D., 2007 - A conceptual model of the flow and distribution of organic carbon in caves. Journal of Cave and Karst Studies, 69: 279-284.

Stewart E., 2012 - Growing unculturable bacteria. Journal of Bacteriology, 194: 4151-4160.

http://dx.doi.org/10.1128/JB.00345-12

Summers Engel A. \& Northup D., 2008 - Caves and karst as model systems for advancing the microbial sciences. In: Martin J. \& White W. (Eds.), Frontiers of karst research. Karst Water Institute, Special publication 13, p. 37-48.

Šebela S., Vaupotič J., Košt’ák B. \& Stemberk J., 2010 - Direct measurement of present-day tectonic movement and associated radon flux in Postojna Cave, Slovenia. Journal of Cave and Karst Studies, 72: 21-34. http://dx.doi.org/10.4311/jcks2009es0077

Šebela S. \& Mulec J., 2011 - Activities in karst of Slovenia related to earthquake precoursors. Ilia State University, Tbilisi, p. 147-156.

Šebela S. \& Turk J., 2011 - Local characteristic of Postojna Cave climate, air temperature, and pressure monitoring. Theoretical and Applied Climatology, 105: 371-386. http://dx.doi.org/10.1007/s00704-011-0397-9
Šbela S., 2012 - Postojna-Planina cave system, Slovenia. In: White W.B. \& Culver D.C. (Eds.), Encyclopedia of caves. Elsevier, Amsterdam, p. 618-624. http://dx.doi.org/10.1016/B978-0-12-383832-2.00091-8

Šebela S., Prelovšek M. \& Turk J., 2013 - Impact of peak period visits on the Postojna Cave (Slovenia) microclimate. Theoretical and Applied Climatology, 111: 51-64. http://dx.doi.org/10.1007/s00704-012-0644-8

Šebela S. \& Turk J., 2014 - Natural and anthropogenic influences on the year-round temperature dynamics of air and water in Postojna show cave, Slovenia. Tourism Management, 40: 233-243. http://dx.doi.org/10.1016/j.tourman.2013.06.011

Šebela S., Turk J. \& Pipan T., 2015 - Cave microclimate and tourism: towards 200 years (1819-2015) at Postojnska jama (Slovenia). Cave and Karst Science, 42: $78-85$.

Warscheid T. \& Braams J., 2000 - Biodeterioration of stone: a review. International Biodeterioration \& Biodegradation, 46: 343-368. http://dx.doi.org/10.1016/S0964-8305(00)00109-8

White D., Pinkart H. \& Ringelberg D., 1997 - Biomass measurements: biochemical approaches. In: Hurst C., Knudsen G., McInerney M., Stetzenbach L. \& Walter M. (Eds.), Manual of environmental microbiology. ASM Press, Washington DC, p. 91-101.

Wynn-Williams D. \& Edwards H., 2002 - Environmental $U V$ radiation: biological strategies for protection and avoidance. In: Horneck G. \& Baumstark-Khan C. (Eds.), Astrobiology. Springer, Berlin, Heidelberg, p. 245-260.

http://dx.doi.org/10.1007/978-3-642-59381-9 17

Zupančič N., Šebela S. \& Miler M., 2011 - Mineralogical and chemical characteristics of black coatings in Postojna Cave System. Acta Carsologica, 40: 307-317. http://dx.doi.org/10.3986/ac.v40i2.15 